\title{
Induction and apoptotic regression of lung adenocarcinomas by regulation of a $K$-Ras transgene in the presence and absence of tumor suppressor genes
}

\author{
Galen H. Fisher, ${ }^{1,7}$ Shari L. Wellen, ${ }^{1}$ David Klimstra, ${ }^{3}$ Joi M. Lenczowski, ${ }^{2}$ Jay W. Tichelaar, ${ }^{5}$ \\ Martin J. Lizak, ${ }^{6}$ Jeffrey A. Whitsett, ${ }^{5}$ Alan Koretsky, ${ }^{6}$ and Harold E. Varmus ${ }^{1,4,8}$ \\ ${ }^{1}$ Varmus Laboratory and ${ }^{2}$ Dermatology Branch, National Cancer Institute, Division of Basic Sciences, National Institutes of \\ Health, Bethesda, Maryland 20892, USA; ${ }^{3}$ Department of Pathology and ${ }^{4}$ Program in Cell Biology, Memorial Sloan-Kettering \\ Cancer Center, New York, New York 10021, USA; ${ }^{5}$ Cincinnati Children's Hospital, Cincinnati, Ohio 45229, USA; ${ }^{6}$ MRI \\ Research Facility and Mouse Imaging Facility, National Institute of Neurological Disorders and Stroke, National Institutes \\ of Health, Bethesda, Maryland 20892, USA
}

To investigate the role of an activated $K$-Ras gene in the initiation and maintenance of lung adenocarcinomas, we developed transgenic mice that express murine $K-R_{a s} 4 b^{G 12 D}$ under the control of doxycycline in type II pneumocytes. Focal proliferative lesions of alveolar type II pneumocytes were observed as early as seven days after induction with doxycycline; after two months of induction, the lungs contained adenomas and adenocarcinomas, with focal invasion of the pleura at later stages. Removal of doxycycline caused a rapid fall in levels of mutant $K$-Ras RNA and concomitant apoptotic regression of both the early proliferative lesions and the tumors. Tumor burden was dramatically decreased by three days after withdrawal, and tumors were undetectable after one month. When similar experiments were performed with animals deficient in either the p53 gene or the Ink4A/Arf locus, tumors arose more quickly (within one month of exposure to doxycycline) and displayed more obvious histological features of malignancy; nevertheless, these tumors also regressed rapidly when the inducer was removed, implying that continued production of mutant K-Ras is necessary to maintain the viability of tumor cells in the absence as well as the presence of tumor suppressor genes. We also show that the appearance and regression of these pulmonary tumors can be readily monitored in anesthetized transgenic animals by magnetic resonance imaging.

[Key Words: Lung cancer; K-Ras; tetracycline; p53; Ink4A; apoptosis]

Received September 25, 2001; accepted October 22, 2001.

Lung cancer is the leading cancer-related death in the United States, with an estimated 157,400 people projected to die of the disease in 2001 (Greenlee et al. 2001). The vast majority $(80 \%-90 \%)$ of cases are related to tobacco smoking; $\sim 10 \%$ of smokers will develop lung cancer with a peak incidence in the fifth and sixth decades of life (Shopland et al. 1991). Adenocarcinoma, a form of non-small cell lung cancer (NSCLC), is the most common type, now accounting for $>40 \%$ of all lung cancer cases (Ginsberg et al. 2001). Analysis of resected tumors has revealed several frequent molecular changes (Salgia and Skarin 1998; Gazdar and Minna 1999; Forgacs et al. 2001). K-Ras is mutated to an activated form in $\sim 30 \%$ of

\footnotetext{
${ }^{7}$ Present address: Department of Dermatology, Medical University of South Carolina, 171 Ashley Avenue, Charleston, SC 29425, USA. ${ }^{8}$ Corresponding author.

E-MAIL varmus@mskcc.org; FAX (212) 717-3299.

Article and publication are at http://www.genesdev.org/cgi/doi/10.1101/ gad.947701.
}

NSCLCs, $c-M y c$ is up-regulated in $20 \%-30 \%$, the p53 tumor suppressor gene is mutated or deleted in $~ 50 \%$, and the Ink4A/Arf locus is often deleted or hypermethylated. $K$-Ras mutations are also observed in a substantial number of sporadic and chemically induced lung adenocarcinomas in mice (Manam et al. 1992; Cazorla et al. 1998; Tuveson and Jacks 1999).

The probable precursors to lung adenocarcinomas are either type II alveolar epithelial cells or Clara cells (Malkinson 1991; Rehm et al. 1991). Transgenic mouse models of lung cancer have been produced by expressing potent viral oncogenes in these cell types (Glasser et al. 1994). Although such models confirm that type II pneumocytes and Clara cells are likely precursors to lung adenocarcinomas, they have not been built with the genes known to be altered in human lung cancer. Another limitation, as in all traditional transgenic models, is that the transgene may be expressed during development and thus may not mimic somatically acquired mutations ac- 
Fisher et al.

curately. Recently, Johnson et al. (2001) described a novel mouse model that depends on spontaneous recombination events at a disrupted, endogenous $K$-Ras locus to generate intact mutant alleles, documenting a role for mutant K-Ras in the formation of lung adenocarcinomas.

Mouse tumor models that conditionally express transgenes (e.g., under the control of elements responsive to tetracycline-related antibiotics) have at least two advantages over conventional transgenic mice. First, the transgene can, in principle, be turned on at any time and thus it resembles a somatic mutation more closely. Second, regulated loss of expression can be used to determine whether a transgene is required for the maintenance, as well as the initiation, of the neoplastic state. This strategy has been used recently to show a requirement for continued expression of mutant $\mathrm{Ha}$-Ras for the maintenance of melanoma in one experimental setting /Chin et al. 1999) and for high levels of c-Myc protein in the maintenance of hematopoietic cell tumors in another (Felsher and Bishop 1999).

In view of the evidence implicating mutant $K$-Ras in the pathogenesis of lung tumors and the experimental advantages of regulated transgenes, we have generated a mouse model of pulmonary adenocarcinoma in which expression of a mutant active $K$-Ras transgene is controlled in type II alveolar epithelial cells by inclusion of doxycycline, a tetracycline analog, in the diet. With this model, we show a role for $K$-Ras in lung tumorigenesis and show that tumors rapidly regress as a result of apoptosis when doxycycline is withdrawn, even in the absence of important tumor suppressor genes.

\section{Results \\ Production of mice with a Tet-regulated $\mathrm{K}-\mathrm{Ras}$ oncogene}

To generate mice in which we could regulate the expression of murine $K-R a s 4 b^{G 12 D}$ in type II alveolar epithelial cells, we took advantage of a previously described line of transgenic mice (CCSP-rtTA mice; Tichelaar et al. 2000; Clark et al. 2001) that express the reverse tetracycline trans-activator protein (rtTA) in the desired cell type. The CCSP-rtTA mouse line was generated by injecting, into FVB/N blastocysts, a construct containing the 2.3-kb rat Clara cell secretory protein (CCSP) promoter driving expression of the rtTA coding domain (Fig. 1A).

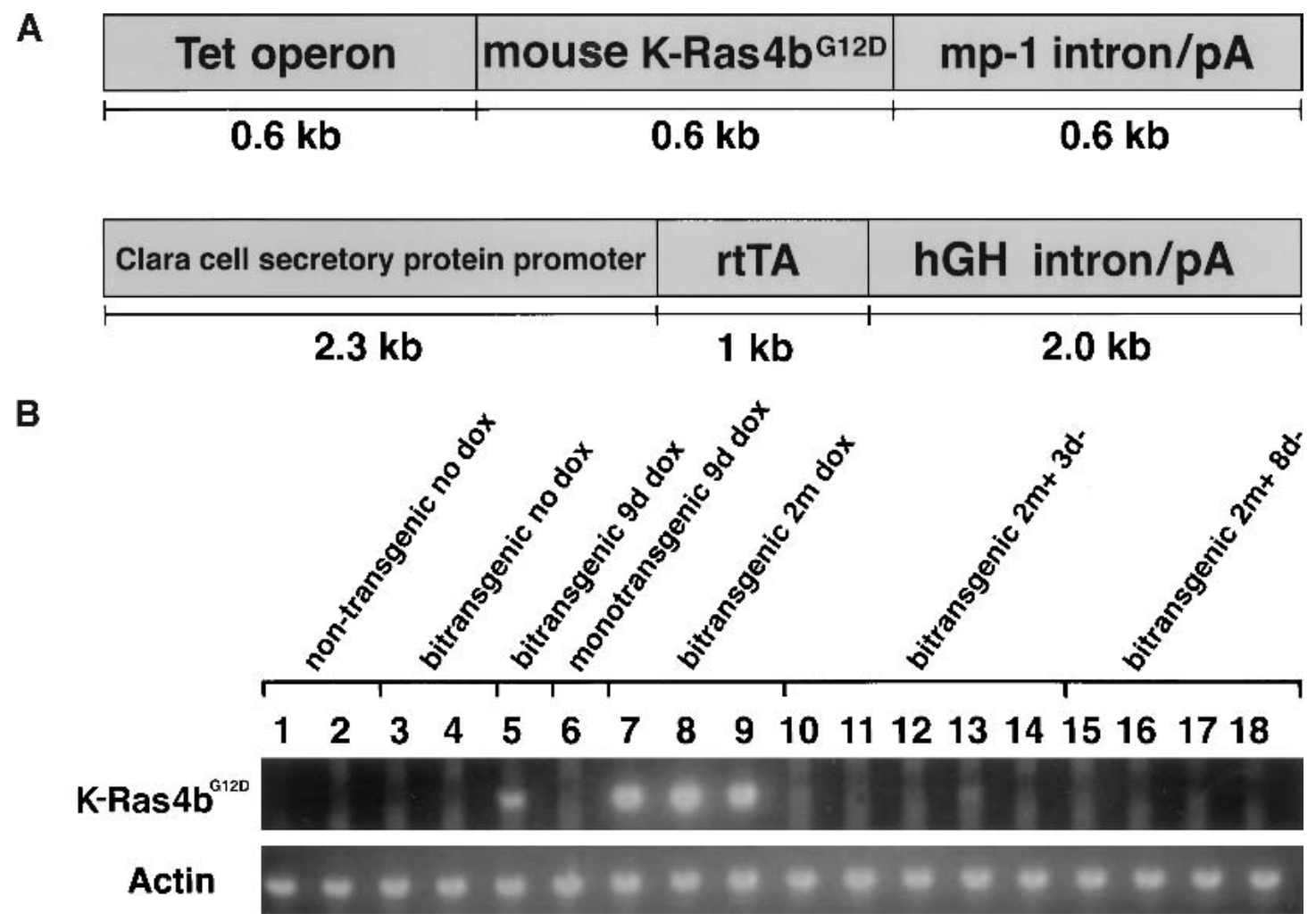

Figure 1. Organization of transgenes and expression patterns. $(A)$ Transgenic constructs used to generate the tetracycline operatorregulated $K$-Ras $4 b^{G 12 D}$ (Tet-op-K-Ras $4 b^{G 12 D}$ ) responder mice (upper) and the Clara cell secretory protein-tet activator (CCSP-rtTA) mice (lower). The origins of the component are described in the text and their sizes are indicated in kilobases (kb). (B) RT-PCR tests for $K$-Ras $4 b^{G 12 D}$ RNA. Total RNA was isolated from the right accessory lobe of 18 different mice and $0.25 \mu \mathrm{g}$ was used for RT-PCR analysis of $K-R a s 4 b^{G 12 D}$ and actin RNAs as described in Materials and Methods. Each sample was run in parallel with a sample lacking RT. Samples were prepared from animals that did not receive doxycycline (nontransgenics, lanes 1,2; bitransgenics, lanes 3,4), from animals that received doxycycline for $9 \mathrm{~d}$ (bitransgenic, lane 5; responder transgene only, lane 6), and from bitransgenic mice that received doxycycline for 2 mo (lanes 7-9) or for 2 mo followed by withdrawal of the inducer for $3 \mathrm{~d}$ (lanes 10-14) or for $8 \mathrm{~d}$ (lanes 15-18). 
The resulting mice were expected to express the tetracycline activator in the Clara cell subset. However, presumably owing to the site of insertion or alterations in the transgene during insertion, at least one founder line expressed rtTA in a pattern that was limited primarily to type II alveolar epithelial cells and allowed expression of transgenes containing the tet operator to be induced dramatically by the addition of doxycycline (Tichelaar et al. 2000; Clark et al. 2001).

To produce mice with a transgene containing a mutant $K$-Ras coding sequence that could be regulated by rtTA and doxycycline, we constructed a 1.8-kb piece of DNA (Fig. 1A) consisting of seven direct repeats of the tetoperator sequence $\left(\right.$ Tet- $\left.\mathrm{O}_{7}\right)$, a murine $K$-Ras $4 b^{G 12 D}$ cDNA (a gift of D. Tuveson and T. Jacks, Massachusetts Institute of Technology), and the mp-1 poly(A) and intron sequence (a gift of E. Holland; Holland and Varmus 1998). Injection of this construct into FVB/N blastocysts produced five $K$-Ras $4 b^{G 12 D}$ transgenic founders, which were then bred to produce lines $\mathrm{KA}, \mathrm{KC}, \mathrm{KE}, \mathrm{KF}$, and $\mathrm{KI}$. Line KI spontaneously developed multiple vascular tumors by the third month of life and was not evaluated further.

Doxycycline induces pathological changes in the lungs of bitransgenic mice

The remaining four transgenic lines were bred to CCSP-rtTA mice and the resulting bitransgenic mice, containing activator and responder transgenes, were divided into groups maintained on untreated water or on water supplemented with doxycycline. These animals were then sacrificed at various ages for histological examination of the lung. Bitransgenic animals derived from responder line KA did not have any discernible lung pathology after 3 mo of doxycycline and were not studied further. However, bitransgenic mice from three other founder lines (KC, KE, and $\mathrm{KF}$ ) developed proliferative alveolar lesions and pulmonary tumors on doxycycline (Fig. 2), but not when maintained on normal drinking water.

As early as 7-14 d after induction with doxycycline, focal hyperplasia of type II pneumocytes occurred in a relatively even distribution throughout the lung fields of these mice, with concentration around peripheral airways and in subpleural regions (Fig. 2A). After sustained induction for 2 mo or more, the hyperplastic lesions progressed to form multiple large, solid-type adenomas or adenocarcinomas in all lung fields.

The early hyperplastic foci consisted of enlarged, cuboidal pneumocytes growing in a confluent fashion within the alveoli; they did not have atypical nuclei. The solid adenomas contained nodular aggregates of similar pneumocytes filling alveolar spaces, with lepidic spread along alveolar septa at the periphery. Solid adenomas had cytoplasmic inclusions and were associated with a secondary population of macrophages within the adenomas; however, they had normal appearing nuclei and lacked stromal elements or demonstrable invasive growth. In the adenocarcinomas, the architecture was more com- plex and a mild nuclear atypia was noted (see Fig. 6A, below). Cytoplasmic inclusions and macrophages were less abundant than in the adenomas, and fibrosis occurred in areas of overlying pleura, without a stromal element in the tumors themselves.

To ascertain the cell type of the adenocarcinomas and their malignant character, the tumor samples were treated with a variety of staining procedures (Fig. 2B-D). Trichrome staining showed local invasion of the pleura by small clusters of tumor cells in areas of pleural fibrosis (Fig. 2B). Consistent with a type II pneumocyte, the tumors express prosurfactant protein $\mathrm{C}$ (SP-C) but not the Clara cell marker CC10 (CCSP), which is seen, as expected, in cells lining the airways (Fig. 2C,D).

After 3 mo on doxycycline, the lungs of bitransgenic animals have such a high tumor burden that they appear by gross inspection to be nearly twice as large as lungs from bitransgenic animals not exposed to inducer (Fig. $2 \mathrm{E}$ ); this was confirmed by weighing the lungs (see Fig. 5, below).

The lungs harvested from $>20$ uninduced bitransgenic animals 3-8 mo of age appeared normal histologically (data not shown). In addition, monotransgenic $K$-Ras $4 b^{G 12 D}$ responder mice did not develop lung lesions after 2 mo of doxycycline stimulation (data not shown). Further studies suggested that all three bitransgenic lines (from KC, KE, and KF) had indistinguishable phenotypes; lines KC and KE were used for all studies reported here.

\section{Measurement of mutant K-Ras RNA in lung tissues from bitransgenic mice}

To confirm that the Tet-op-K-Ras $4 b^{G 12 D}$ cassette in the bitransgenic mice is regulated in the predicted fashion, we initially used conventional RT-PCR with transgenespecific primers to detect mutant $K$-Ras RNA before and after addition of doxycycline. For both lines KE and KC, mutant $K$-Ras RNA was undetectable in total lung RNA from uninduced bitransgenic mice (Fig. 1B, lanes 3,4) and from monotransgenic Tet-op-K-Ras mice treated with doxycycline (Fig. 1B, lane 6). However, when bitransgenic animals were fed doxycycline, $K$-Ras $4 b^{G 12 D}$ RNA was readily detectable in lung samples from the earliest time point (9 d; Fig. 1B, sample 5). Using a more quantitative assay with the Taq-Man method (Orlando et al. 1998), a very low level of mutant K-Ras RNA was detected in the absence of doxycycline (Table 1). The level increased $\sim 500$-fold in lung tissue from mice treated with doxycycline for $9 \mathrm{~d}$, a time at which $<5 \%$ of the lung fields is composed of proliferative lesions. If all cells in the tissue sample actually express the transgenic RNA, then the level of the mutant RNA would be $2 \%$ that of the endogenous $K$-Ras $4 b$. If, however, induction of mutant K-Ras RNA occurred only in those cells that displayed the proliferative responses (approximately one-twentieth of all cells), then the induction ratio in those cells would be $\sim 10,000$-fold $(20 \times 500)$ and the induced level of transgenic RNA would be $40 \%(20 \times 2 \%)$ as high as the endogenous $K$-Ras $4 b$ RNA. 
Fisher et al.

A
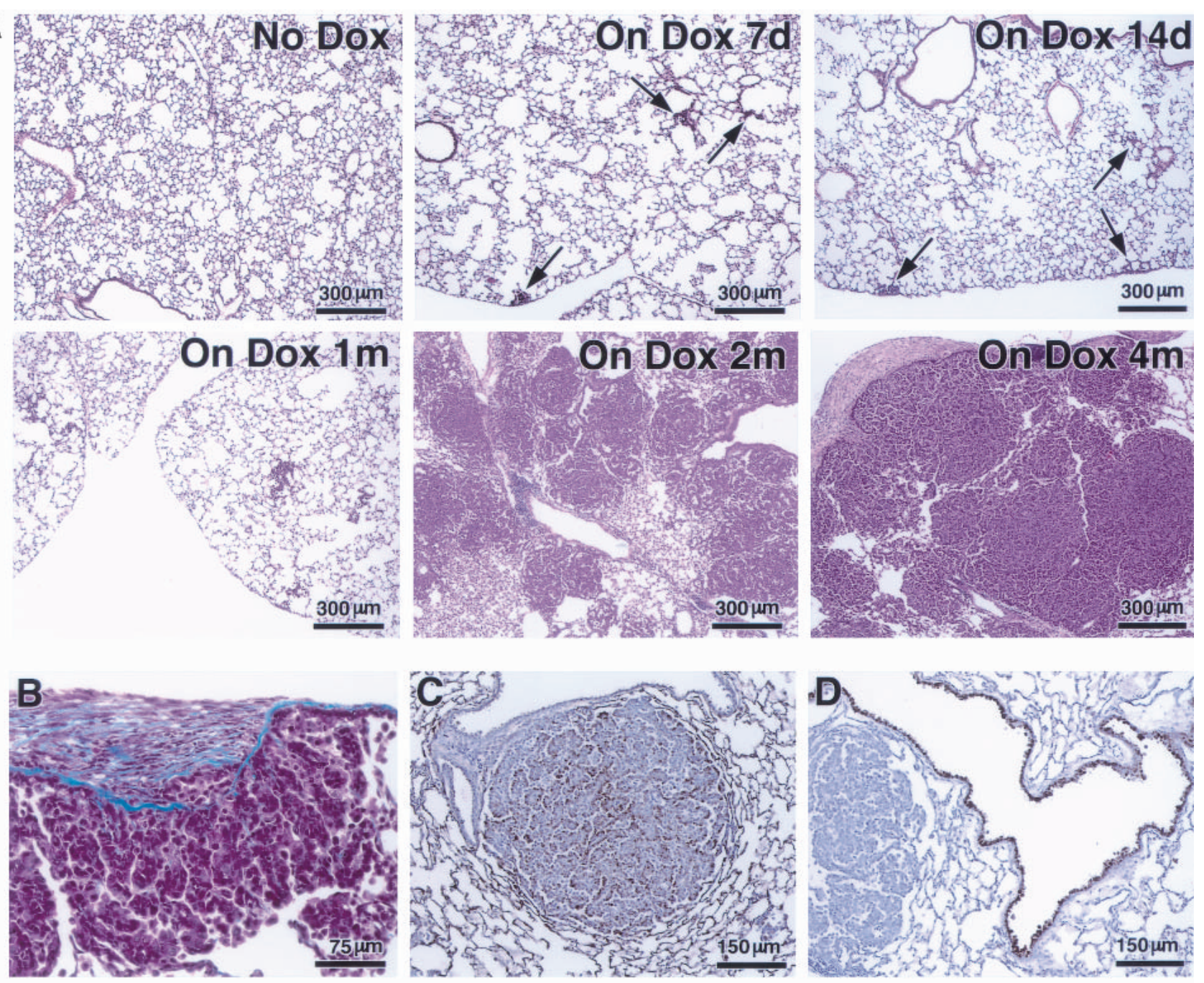

$\mathbf{E}$

On Dox 3m

No Dox

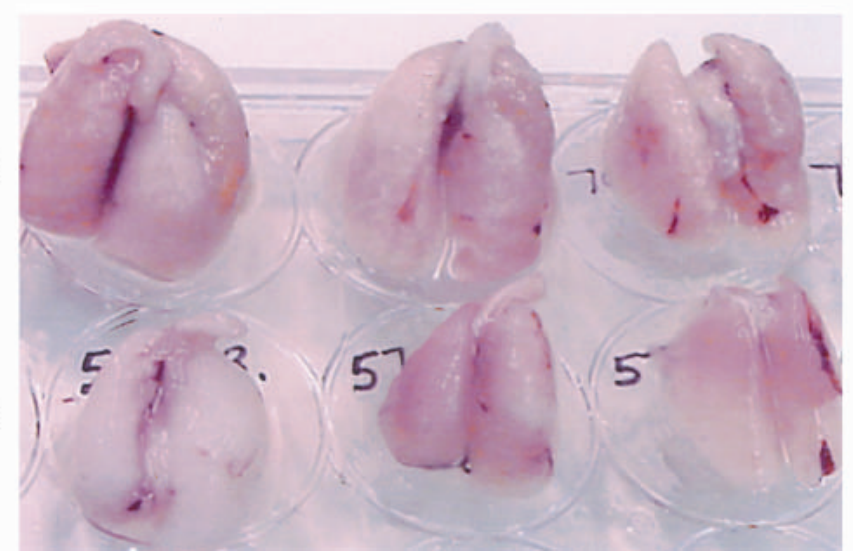

Figure 2. Appearance of proliferative foci and tumors after induction of mutant K-Ras with doxycycline. $(A)$ Kinetics of induction of histological changes. Samples of lung tissue were stained with hematoxylin and eosin after exposure to inducer for $7 \mathrm{~d}$, $14 \mathrm{~d}$, and 1 , 2 , and $4 \mathrm{mo}$, as indicated. (B) Trichrome stain of tumor from a bitransgenic mouse treated for 4 mo shows invasion of stroma by tumor cells. $(C, D)$ Cell-type-specific staining of a tumor from a mouse treated for 2 mo with doxycycline indicates properties of type II pneumocytes. Positive staining for Prosurfactant protein $\mathrm{C}(C)$ and negative staining of the tumor but positive staining of the airways for Clara cell secretory protein (CCSP; $D)$. (E) Photographs of intact lungs from three bitransgenic mice induced with doxycycline for 3 mo (top row), compared to lungs from non-induced bitransgenic mice (bottom row). 
Table 1. Quantitative analysis of endogenous and transgenic $\mathrm{K}-\mathrm{Ras} 4 \mathrm{~b}$ RNA in nontransgenic and bitransgenic mice treated with doxycycline for the times indicated

\begin{tabular}{lcc}
\hline & K-Ras $4 b^{\text {G12D }}$ & $\begin{array}{c}\text { Endogenous } \\
\text { K-Ras } 4 b\end{array}$ \\
\hline Nontransgenic & $<0.00001$ & 1.0 \\
Bitransgenic, No Dox & $0.000045^{\star}$ & 1.1 \\
Bitransgenic, 9d Dox & 0.02 & 0.56 \\
Bitransgenic, 2m Dox & 1.1 & 0.41 \\
Bitransgenic, On 2m Off 3d & $0.00016^{\star}$ & 0.54 \\
\hline
\end{tabular}

Total RNA was prepared from the right accessory lobe and used for quantitative Taq-Man ${ }^{\mathrm{TM}}$ RT-PCR as described in Materials and Methods. Each sample was amplified for endogenous $K$-Ras $4 b$, transgenic $K$-ras $4 b^{G 12 D}$, and GAPDH. After amplification, data was plotted and, for each individual sample, amplification curves for both endogenous and transgenic $K$-Ras message was standardized to GAPDH. We arbitrarily designated the level of $K-R a s 4 b$ in nontransgenic mice equal to 1 . We then compared the GAPDH-standardized levels of endogenous and transgenic $K$-Ras message to the level of endogenous $K$-Ras seen in the nontransgenic sample. The amplification curves indicated that the mutant and endogenous $K$-Ras RNAs were amplified with nearly identical efficiencies (data not shown). Standard deviations determined after multiple assays were in the range of $5 \%$ to $20 \%$ excepting the two low abundance samples (indicated with an asterisk) where the signal was near background and the standard deviation was about $50 \%$.

Tests of tumor-bearing lungs from bitransgenic animals treated for 2 mo with doxycycline revealed a five$\log$ induction of the $K$-Ras transgene RNA (Table 1). Despite this impressive induction ratio, the amount of transgene-derived RNA per cell was similar to that of endogenous $K$-Ras $4 b$ RNA in nontransgenic mice (Fig. 1B, lanes 7-9; Table 1). Because at least half of the cells in these lungs are tumor cells, the values determined by Taq-Man-based PCR are likely to be within twofold of the actual average level per tumor cell. In parallel analyses, we repeatedly observed a twofold decline in endogenous $K$-Ras $4 b$ transcripts in the lungs of doxycyclineinduced bitransgenic animals (Table 1); the possible significance of this observation is considered in the Discussion.

\section{Mutant K-Ras promotes proliferation of type II pneumocytes}

Expression of mutant Ras genes in cells can promote proliferation or apoptosis, depending on growth conditions and cell type (for review, see Downward 1998). To test for cellular proliferation during doxycycline-mediated induction of mutant $K$-Ras in bitransgenic mice, we injected animals with bromodeoxyuridine (Brdu) and several hours later harvested lung tissue for detection of cells that had incorporated Brdu during DNA replication (Fig. 3). We observed $<1 \%$ of Brdu-positive cells distributed uniformly in lungs from uninduced bitransgenic (Fig. 3A) and non-transgenic mice (data not shown).
These finding are consistent with previous measurements of cells undergoing DNA replication in adult mouse lungs (Zsengeller et al. 1999). In contrast, focal areas of Brdu-positive cells, colocalizing with foci of hyperplastic cells, were found in the lungs of bitransgenic mice fed doxycycline for $14 \mathrm{~d}$ (Fig. 3B); foci of proliferating cells could be convincingly detected as early as $3 \mathrm{~d}$ of induction (data not shown). Outside the hyperplastic areas, however, we did not observe any increase or decrease in the number of cells incorporating Brdu after induction (data not shown). As expected, many cells incorporated Brdu in adenomas and adenocarcinomas in lungs from bitransgenic mice maintained on doxycycline (Fig. 3C).

\section{Mutant K-Ras is required for tumor maintenance}

In the preceding sections, we showed that induction of a mutant $K$-Ras transgene in type II alveolar epithelial cells several weeks after birth can initiate cell proliferation and formation of tumors. To determine whether $K$-Ras $4 b^{G 12 D}$ has a role in maintaining, as well as in initiating, these tumors, we took advantage of the opportunity to down-regulate the mutant $K$-Ras transgene by withdrawing doxycycline from the diet of tumor-bearing mice.

First, we assessed the effect of the withdrawal of the inducer, doxycycline, on the abundance of mutant $K$-Ras RNA. Although the mice had received doxycycline for 2 mo, within $3 \mathrm{~d}$ after withdrawal of the drug, K-Ras $4 b^{G 12 D}$ RNA returned to levels indistinguishable from or only slightly higher than those observed in lungs from uninduced mice, as measured by conventional RT-PCR or Taq Man assays (Fig. 1B, lanes 10-14; Table 1); after $8 \mathrm{~d}$ of withdrawal, RT-PCR products were undetectable (Fig. 1B, samples 15-18). Concomitant with this rapid decline in mutant $K$-Ras RNA, by 3 d after withdrawal we observed a decline of Brdu incorporation to levels found in uninduced lungs (Fig. 3D).

More importantly, the tumors regressed rapidly after doxycycline withdrawal (Figs. 4, 5). By $3 \mathrm{~d}$ after withdrawal of long-term doxycycline treatment, the lung surfaces were grossly pitted (Fig. 4C); histologic sections of the tumors revealed reduced cellular density compared with tumors from animals still on doxycycline, with significant amounts of nuclear condensation and debris (Fig. 4A,B). By 7 d after doxycycline withdrawal, only sparse patches of hyperplastic growths were present and no residual tumor tissue was found in lungs from five bitransgenic mice after doxycycline was removed from the diet for 1 mo (Fig. 4A).

These dramatic changes were also documented quantitatively by weighing the lungs at the time of death. Within 2 mo of K-Ras induction with doxycycline, tumor-laden lungs from bitransgenic mice weigh significantly more than normal lungs; the weight declines rapidly on withdrawal of inducer and returns to near normal levels in a month (Fig. 5). 

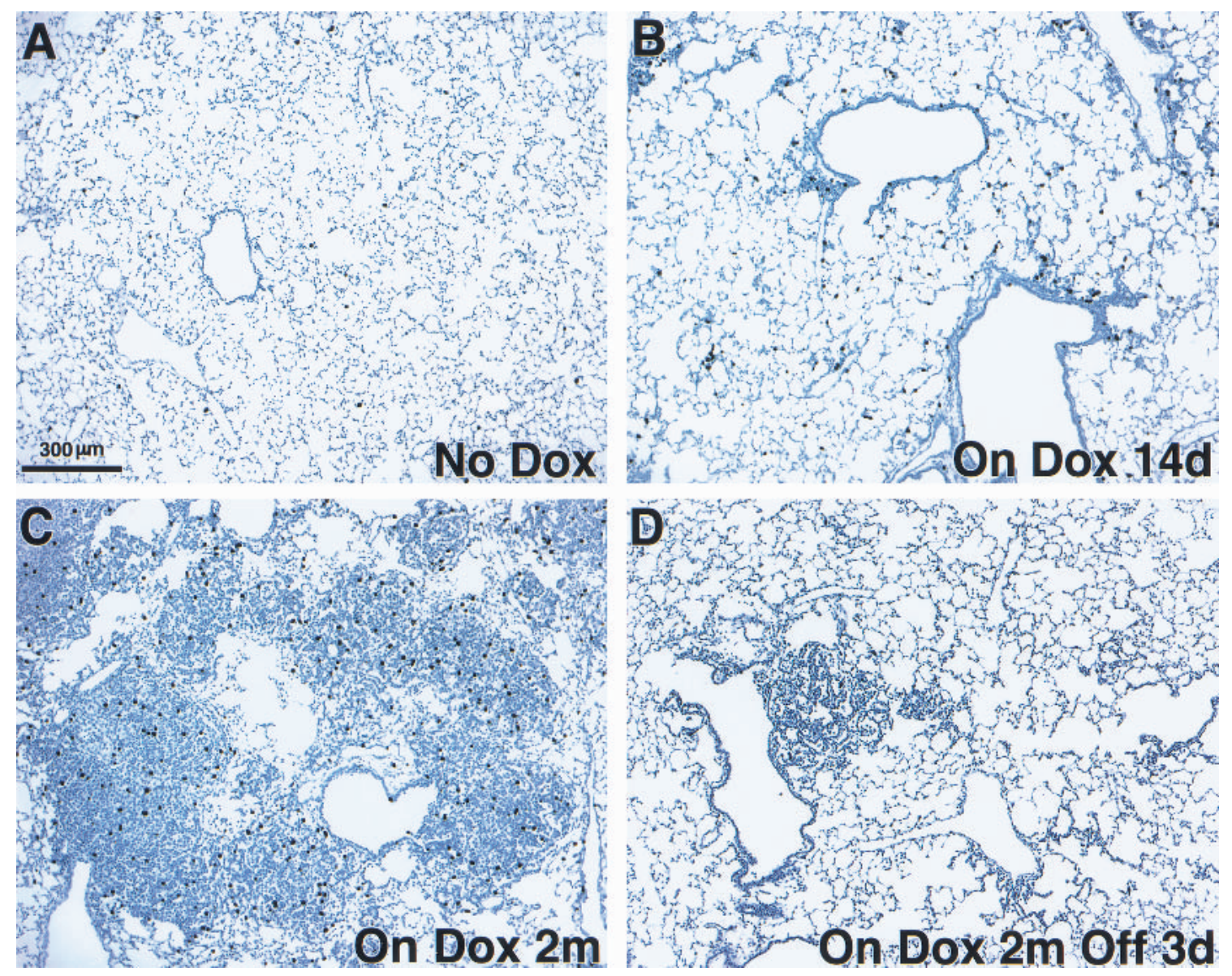

Figure 3. Induction of mutant $K$-Ras with doxycycline promotes lung cell proliferation. The relative proportions of proliferating lung cells were determined by injection of Brdu and immunohistochemical staining after $3 \mathrm{~h}$ incorporation in bitransgenic mice that did not receive inducer $(A)$, that received inducer for $14 \mathrm{~d}(B)$ or $2 \mathrm{mo}(C)$, and that had inducer withdrawn for $3 \mathrm{~d}$ following $2 \mathrm{mo}$ of treatment $(D)$.

\section{Tumor regression is mediated by apoptosis}

The rapid loss of tumor mass, the pitted lung surface, and the appearance of pyknotic nuclei suggested that regression was occurring via an apoptotic mechanism. To address this possibility more specifically, we performed TUNEL assays (see Materials and Methods) for evidence of the damaged DNA characteristic of apoptotic cells, using tumor samples from bitransgenic mice on doxycycline and from mice recently removed from the inducer (Fig. 4B). We did not observe significant numbers of apoptotic cells in nontumorous areas of the lungs, in endothelial cells, or in lungs from uninduced bitransgenic or nontransgenic mice (data not shown). However, tumor regression was accompanied by a vigorous apoptotic response, with a marked increase in TUNEL-positive tumor cells.

To determine whether the withdrawal of inducer eliminated all cells with the potential to form tumors, we placed a cohort of seven bitransgenic mice on the following induction scheme: doxycycline induction for $1 \mathrm{mo}$, withdrawal for $1 \mathrm{mo}$, and subsequent re-induction for $1 \mathrm{mo}$. At the end of this protocol, all seven mice had lung lesions that were indistinguishable from those observed in mice that had been exposed only to one round of doxycycline for $1 \mathrm{mo}$ (data not shown). This is consistent with at least two possibilities. Regression-associated apoptosis might spare one or more cells that can then act as tumor progenitors. Alternatively, all cells in the original lesions might undergo apoptosis, but other type II cells not previously induced to form tumor cells might now act as precursors. In either case, the resulting lesions did not appear more aggressive, as they might had additional mutations occurred.

$\mathrm{K}-\mathrm{Ras}$-induced lung tumors arise faster in the absence of tumor suppressor genes p53 or Ink4A/Arf

In the results presented thus far, both production and maintenance of lung tumors depend on expression of mutant $K$-Ras. However, we have not attempted to determine whether the tumors have accumulated other mutations affecting proto-oncogenes or tumor suppressor genes. Because it is important to know whether other mutations can collaborate with the mutant $K$-Ras gene 

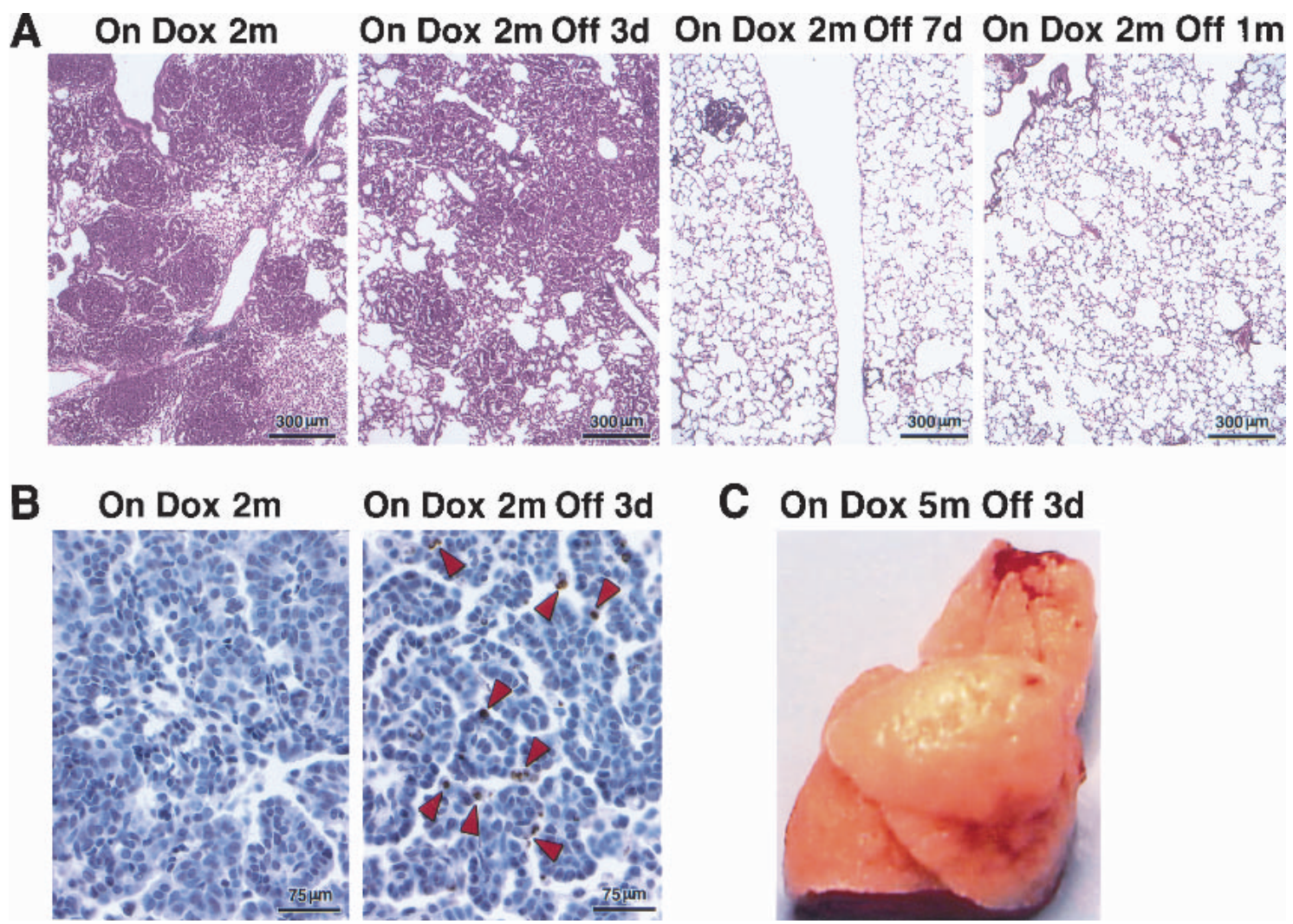

Figure 4. Effects of withdrawal of doxycycline and deinduction of mutant $K$-Ras on lungs of bitransgenic mice. $(A)$ Tumor regression. Sections of lungs from bitransgenic mice treated with doxycycline for $2 \mathrm{mo}$ and after removal of the inducer for $3 \mathrm{~d}, 7 \mathrm{~d}$, or $1 \mathrm{mo}$ were stained with H\&E. (B) Appearance of apoptotic cells. Lung tumor samples were assayed for apoptotic cells using the TUNEL procedure after 2 mo on doxycycline (left) and $3 \mathrm{~d}$ after removal of the inducer (right). Examples of TUNEL-positive cells are indicated by red arrowheads. $(C)$ "Pitting" on the surface of an intact lung from a bitransgenic mouse that received doxycycline for 5 mo and then had the inducer withdrawn for $3 \mathrm{~d}$. The sample was fixed and dehydrated before photography.

to induce tumors and, especially, to know whether down-regulation of mutant $K$-Ras RNA causes apoptosis and tumor regression under such circumstances, we have examined the induction and de-induction of mutant $K$-Ras in bitransgenic mice bred into a background deficient for tumor suppressor genes.

For these experiments, we used previously reported mice lacking an intact p53 gene (Jacks et al. 1994) or an Ink4A/Arf locus (Serrano et al. 1996). In the absence of either p53 or the Ink4A/Arf locus, doxycycline-mediated induction of $K$-Ras $4 b^{G 12 D}$ initiated lung tumorigenesis significantly more rapidly than in a wildtype background. Within 1 mo of treatment with doxycycline, the extent of adenocarcinoma growth in the lungs of bitransgenic $p 53^{-/-}$or Ink $4 A / A r f^{-/-}$mice was similar to that found in bitransgenic wild-type mice fed doxycycline for 2 mo or more, as evaluated histologically under low power (Fig. 6B) or by lung weight (Fig. 5).

High power views of these tumors (Fig. 6A) revealed several features consistent with a more malignant phenotype. Tumors arising in a wild-type background (Fig. 6A, left) have a predominantly solid architecture, with minimal stromal components and mildly or moderately atypical nuclei. When $p 53$ is absent (Fig. 6A, center), the architecture is unchanged but the nuclei are markedly pleomorphic and some cells exhibit prominent cytoplasmic vacuolization. In the Ink $4 A / A r f$-deficient background (Fig. 6A, right), the architecture is distinctly papillary and the cells are columnar, with basal, moderately atypical nuclei, apical cytoplasmic blebbing, and intracellular mucin.

Lung tumors arising in the absence of tumor suppressor genes remain dependent on mutant K-Ras for maintenance of tumor growth: apoptosis after K-Ras down-regulation does not require p53 or Ink4A/Arf

When mice bearing lung tumors that developed in the absence of $p 53$ or Ink4A/Arf were deprived of doxycycline, the tumors regressed just as quickly as did tumors in a wild-type background (see Fig. 6B for histological changes and Fig. $5 \mathrm{~B}, \mathrm{D}$ for changes in lung weight). TUNEL assays confirmed that the regression was occurring by apoptosis (data not shown). The products of both p53 and p19(Arf) genes have been implicated in some apoptotic pathways (Lowe 1999; Sherr and Weber 2000; Vousden 2000). However, our results indicate that the 
Fisher et al.

(A)

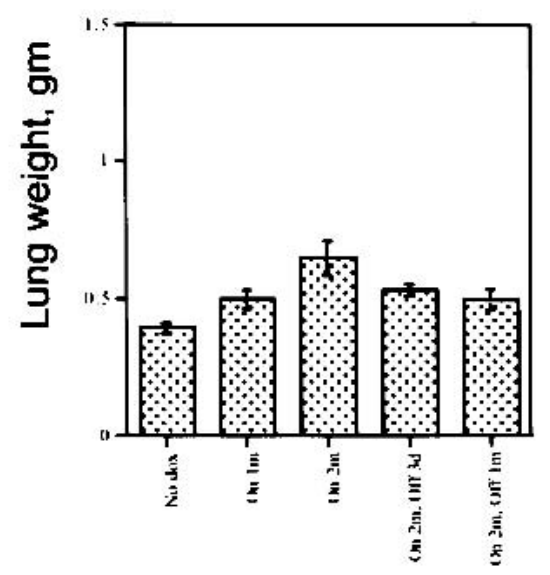

(C)

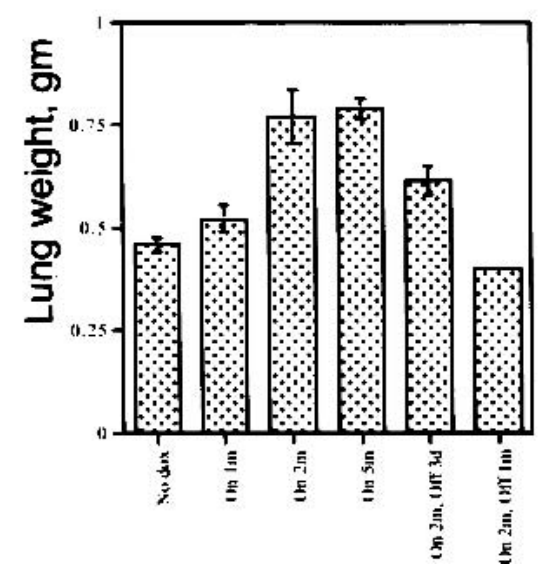

(B) Mixed Background Ink 4A-/-

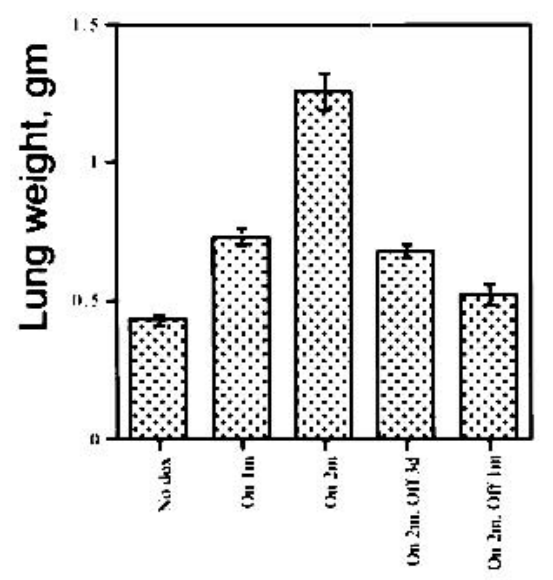

(D)
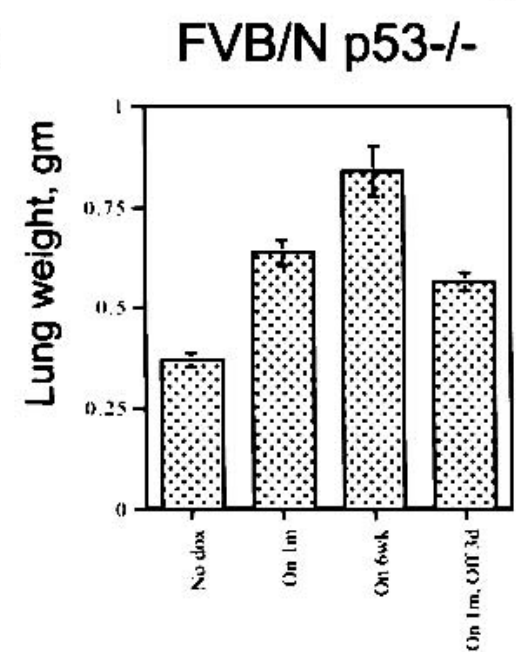

Figure 5. Increase and decrease in the weight of lungs from $K$-Ras bitransgenic mice treated with doxycycline and subjected to withdrawal of the inducer. Weights were determined after excision, fixation in $4 \%$ paraformaldehyde, and dehydration in $70 \%$ ethanol. The bitransgenic mice were from a mixed genetic background $(A)$, a mixed background with a mutation affecting Ink $4 A / A r f(B), \mathrm{FVB} / \mathrm{N}$ $(C)$, and an $\mathrm{FVB} / \mathrm{N}$ background with a mutation affecting $p 53(D)$.

tumor cell apoptosis following down-regulation of mutant $K$-Ras can occur independently of $p 53$ and $\operatorname{Ink} 4 A / A r f$.

\section{Lung tumor growth and regression can be monitored} in live mice with $M R I$

In the experiments presented thus far, we have used cohort-based studies to make claims about the role of $K$-Ras in the induction and maintenance of lung tumors, killing animals exposed to doxycycline for varied times for histological examination. To confirm our conclusions in single living animals by monitoring tumor growth and regression over time, we performed serial MRI scans on bitransgenic mice, using a gated recording method on a 4.7 Tesla MRI machine (Fig. 7). After 3 mo of exposure to doxycycline, multiple tumor masses were evident in both lung fields of a bitransgenic mouse; a striking reduction of tumor volume occurred within $8 \mathrm{~d}$ after removal of doxycycline from the diet of this same mouse. Tumor regression was confirmed histologically by harvesting the lungs following the second MRI scan (data not shown). Consistent with earlier results, more extensive tumor growth was seen in a bitransgenic, Ink $4 A$ /Arf-deficient mouse after 2 mo of doxycycline induction than was observed after 3 mo of induction of a bitransgenic mouse with a tumor-suppressor wild-type background (Fig. 7); again, extensive regression of the tumors occurred within $8 \mathrm{~d}$ after removal of the inducer.

\section{Discussion}

In this study, we have shown that somatic induction of a mutant cDNA, which encodes an activated K-Ras protein commonly found in human lung cancers, induces focal proliferation and tumorigenesis in at least a subset of type II pneumocytes. In addition, tumorigenesis is enhanced when the mutant $K$-Ras transgene is induced in the absence of either of two tumor suppressor loci, p53 or Ink4A/Arf, that are inactivated in many human 

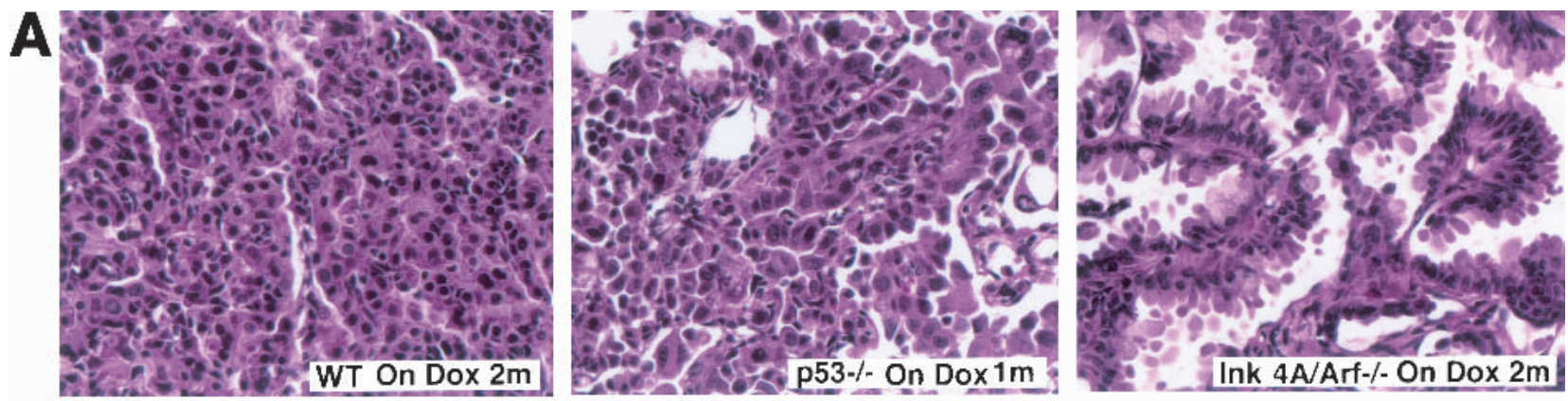

\section{B}
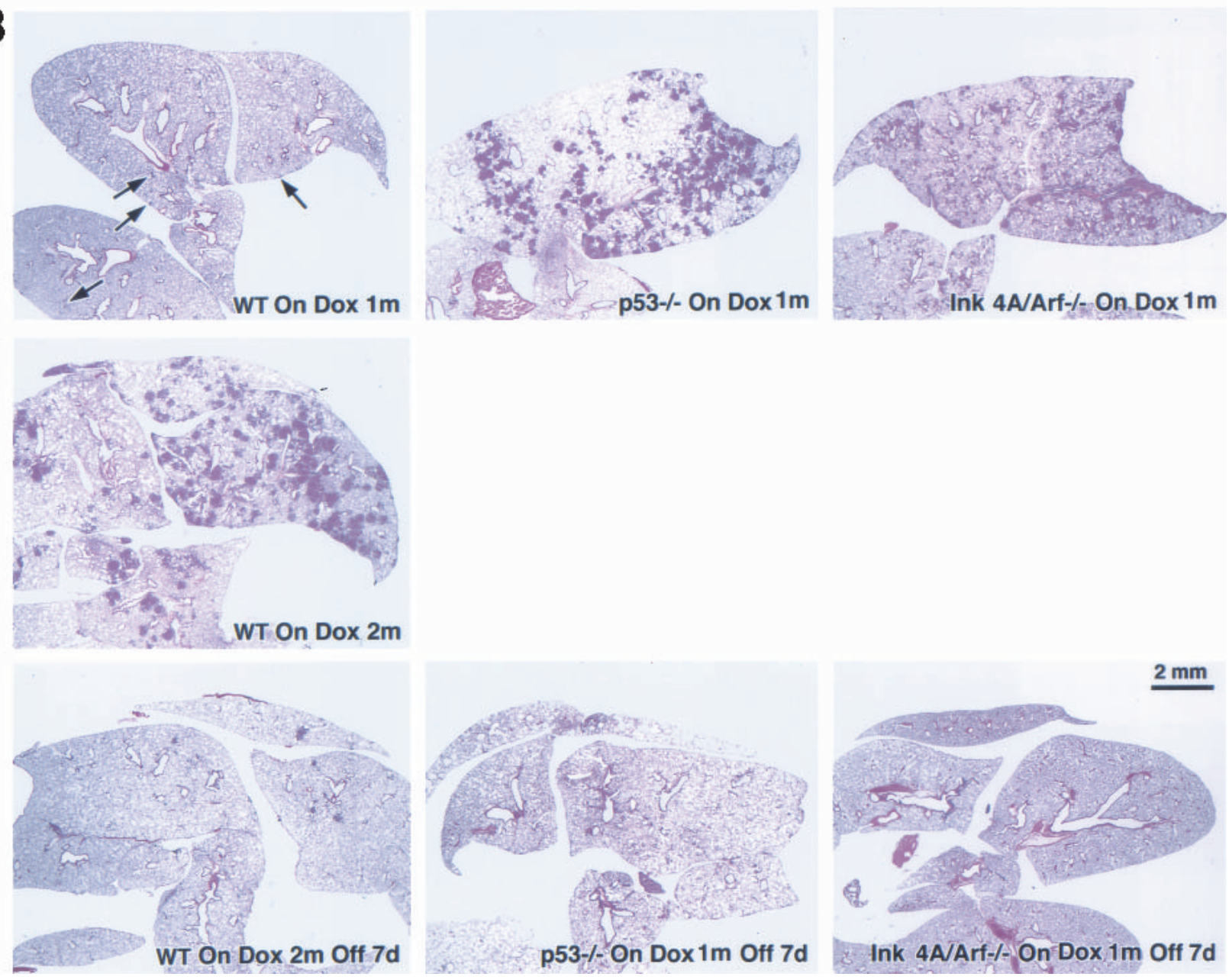

Figure 6. Characterization of tumors arising in $K$-Ras bitransgenic mice in backgrounds of or Ink $4 A / A r f$ deficiencies. $(A)$ Malignant features of histopathology of tumors in the presence and absence of tumor suppressor genes. Samples of H\&E-stained tumor-bearing lungs from indicated mouse strains after induction with doxycycline are shown at 40x magnification; for description, see text. $(B)$ Tumors in tumor-suppressor-gene-deficient backgrounds appear more quickly during induction but regress similarly after doxycycline withdrawal. Lung slices were stained with $\mathrm{H} \& \mathrm{E}$ after exposure of bitransgenic mice to doxycycline for 1 or 2 mo and after withdrawal for $7 \mathrm{~d}$. Bitransgenics in a wild-type background are shown on the left; in a p53-deficient background in the middle; and in an Ink $4 A$ /Arf-deficient background on the right, all as labeled.

NSCLCs. Importantly, we find that tumor maintenance in both the wild-type and tumor suppressor gene-deficient backgrounds requires continued expression of mutant $K$-Ras to prevent rapid regression via $p 53$ - and Ink4A/Arf-independent apoptotic mechanisms.
Mutant K-Ras stimulates proliferation of type II pneumocytes

Although lung cancer is the leading cause of death from cancer in the United States and K-Ras is mutated both in 
On Dox 3m
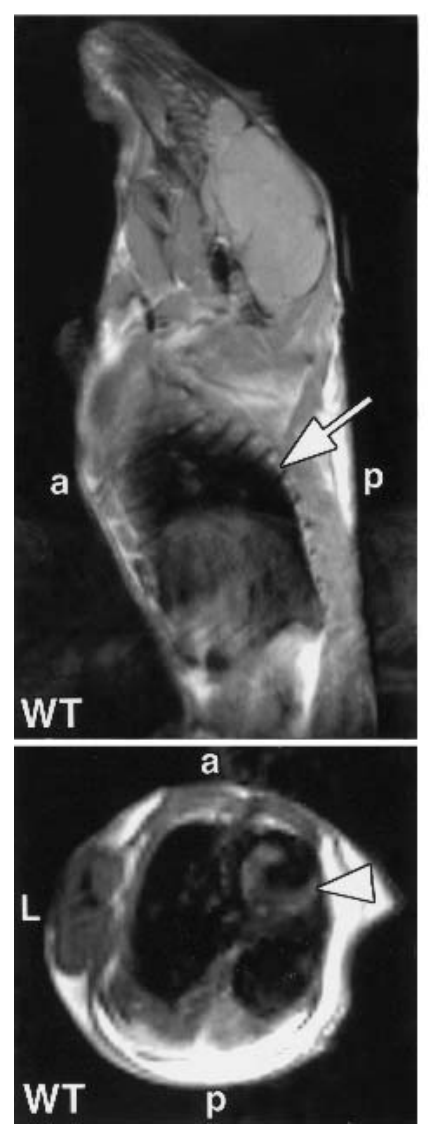

On Dox 3m Off 8d
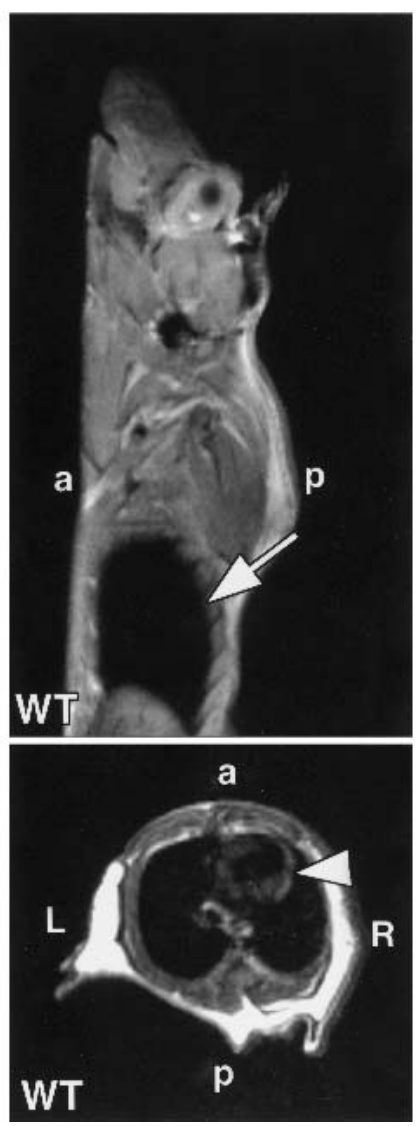

On Dox $2 m$
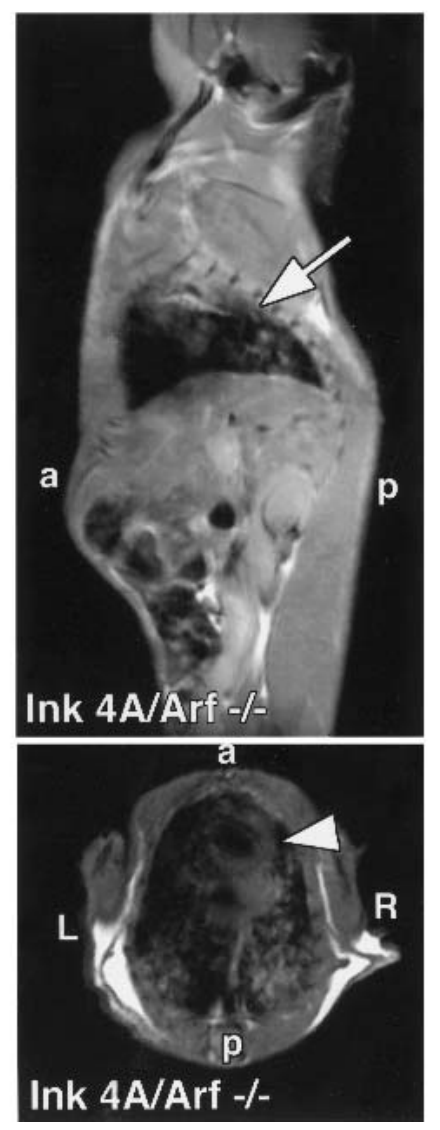

On Dox 2m Off 8d
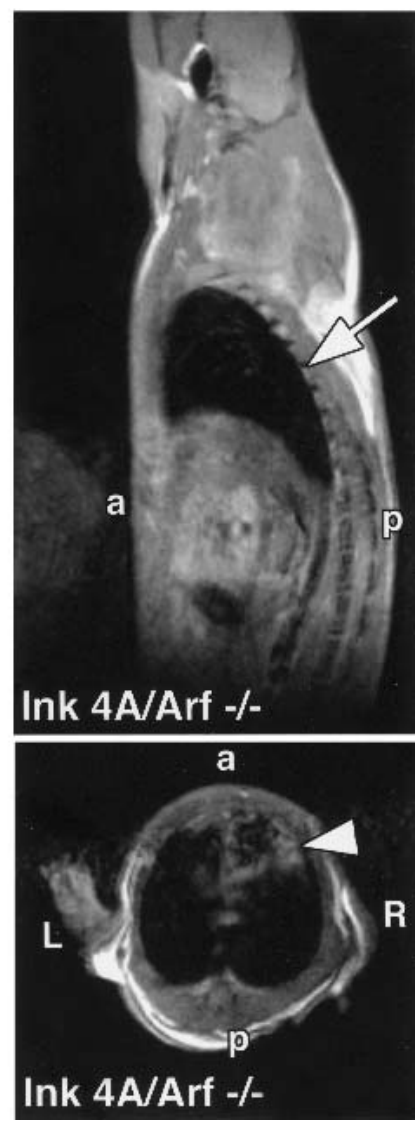

Figure 7. Magnetic resonance imaging of tumor regression. The pictures show sagittal (upper) and transverse (lower) images of lung fields from a bitransgenic mouse without known tumor suppressor gene mutations (left) and another bitransgenic mouse with a mutation affecting Ink4A/Arf (right). Each animal was anesthetized and subjected to MRI after induction with doxycycline for the indicated times and again after $8 \mathrm{~d}$ without the inducer. Arrows indicate positions of the posterior thoracic wall (upper, sagittal sections) and the outer myocardial wall (lower, transverse sections).

a substantial fraction of human lung cancers and in chemically-induced lung cancers in rodents (Salgia and Skarin 1998; Gazdar and Minna 1999; Tuveson and Jacks 1999|, the first K-Ras-based lung cancer model was reported only recently (Johnson et al. 2001). Perhaps surprisingly, in both that study and ours, multifocal adenomatous hyperplasias and tumors appear to occur efficiently without the purposeful introduction of additional insults to proto-oncogenes or tumor suppressor genes.

Our results, those of Johnson et al. (2001), and similar results from a $\mathrm{K}$-Ras-based model produced by A. Berns and his colleagues (Meuwissen et al. 2001) raise the possibility that mutant K-Ras, even at physiologically normal or subnormal levels (Table 1), is sufficient to drive proliferation in at least a subset of type II pneumocytes to form adenomas and adenocarcinomas. These findings may appear paradoxical in view of evidence that mutant Ras induces cell cycle arrest in primary mouse fibroblasts and can cause cell death in some settings (Serrano et al. 1997; Downward 1998). In addition, the prevailing hypothesis concerning tumorigenesis is that primary cells must acquire multiple genetic changes to bring about persistent growth and tumor formation (Kinzler and Vogelstein 1996; Hanahan and Weinberg 2000). These apparent paradoxes invite efforts to define properties of cells that influence the consequences of expressing mutant Ras genes and to seek changes in the content or expression of genes that might collaborate with mutant Ras in tumor formation.

Heterogeneity of cell differentiation and different levels of expression of the CCSP-rtTA transgene in type II epithelial cells might contribute to the focal nature of the proliferative response. Despite several attempts, we have been unable to ascertain directly, by performing assays on individual cells, whether the nonproliferating cells express the $K$-Ras transgene. However, an indirect argument suggests that they do. Expression of mutant $K$-Ras may be responsible for the observed suppression of endogenous $K$-Ras $4 b$ RNA to similar levels in lungs induced for $9 \mathrm{~d}$ (when only a minority of the cells have formed hyperplastic foci) and in tumor-bearing lungs induced for 2 mo (Table 1); if so, it would seem necessary for the majority of target cells to have responded to the inducer by producing sufficient mutant K-Ras to sup- 
press the level of endogenous $K$-Ras $4 b$ message, even though most do not proliferate in response to the oncogenic stimulus.

Our observation that the level of endogenous $K$-Ras $4 b$ RNA is reduced after induction of the mutant $K$-Ras transgene may also be important for producing the oncogenic effects of mutant $K$-Ras, in view of recent evidence that wild-type $K$-Ras can inhibit lung carcinogenesis in mice treated with agents that cause $K$-Ras mutations (Zhang et al. 2001).

\section{Regulated transgenes define requirements for tumor maintenance}

Use of regulated transgenes in mouse tumor models has defined requirements for tumor maintenance in some experimental systems (Chin et al. 1999; Felsher and Bishop 1999). Chin et al. showed that maintenance of growth of melanomas arising after induction of activated $H$-Ras in mice deficient for Ink4A/Arf is dependent on continued expression of the H-Ras transgene. Notably, in their melanoma model, withdrawal of doxycycline is followed by extensive apoptosis of the endothelial cells of the tumor vasculature, as well as tumor cells, whereas in our lung model apoptosis was observed exclusively in tumor cells. This difference may be attributable, in part, to greater requirements for angiogenic events in skin tumors than in lung tumors and to the induction of angiogenic factors, such as vascular endothelial growth factor (VEGF). For instance, we did not observe induction of VEGF RNA in our tumors using Taq-Man RT-PCR (data not shown); also, mutation of $K$-Ras is not associated with elevated amounts of VEGF RNA in human NSCLC (Tsao et al. 1997). Chin et al. also described a subset of tumors that subsequently re-grew in a Ras-independent fashion after withdrawal of inducer. Analogous results have been obtained by Felsher and Bishop (1999) in their studies of hematopoietic tumors induced by regulatable $c-M y c$. Some tumor cell clones gained the ability to grow without expression of $c-M y c$, especially when the system was examined in a p53-deficient background (D. Felsher, pers. comm.). Although we did not see any residual tumor in five bitransgenic mice without known mutations in tumor suppressor genes examined 1 mo after withdrawal, about a third of similarly treated Ink4A/Arf-/- bitransgenic mice had occasional small foci of dysplastic type II pneumocytes (data not shown). This raises the possibility that larger tumors, especially in tumor suppressor-deficient backgrounds, are more likely to contain cells that have acquired accessory mutations that allow re-growth following withdrawal of the inducer.

Three recent reports have shown that lung-specific induction of fibroblast growth factors (FGFs) 3, 7, and 10 produces focal adenomatous hyperplasias and sometimes frank adenomas in bitransgenic mice engineered to respond to tetracycline-like antibiotics (Tichelaar et al. 2000; Clark et al. 2001) or a progesterone antagonist (Zhao et al. 2001). In all three reports, the FGF-stimulated adenomatous growths disappeared rapidly when the inducers were removed and the kinetics of induction and regression of FGF RNA and cell hyperplasia were similar to those observed in the K-Ras model presented here. In the one case in which TUNEL assays for apoptotic cells were reported (Clark et al. 2001), the results were negative; the authors proposed that the loss of adenomatous tissue might be attributable to detachment of epithelial cells from the basal lamina, concomitant with a loss of markers of cell differentiation. Although these three reports indicate a potential role of FGFs in lung tumorigenesis and tumor maintenance, as well as lung development, evidence for a role in human lung cancers has been limited to descriptions of expression patterns of FGFs and their receptors (Berger et al. 1999).

\section{Combining a regulated mutant K-Ras transgene with tumor suppressor gene deficiencies}

Cooperative growth-promoting interactions have long been proposed to occur between mutations observed in human cancer (Kinzler and Vogelstein 1996; Lowe 1999; Hanahan and Weinberg 2000). Our observation that deficiencies of either the $p 53$ gene or the Ink4A/Arf locus accelerate $K$-Ras-driven tumorigenesis is consistent with this hypothesis. In particular, the increased rate of tumor growth in the tumor suppressor gene-deficient bitransgenic mice might have been anticipated based on studies of mutant Ras genes in primary mouse embryonic fibroblasts (Serrano et al. 1997). Serrano and colleagues showed that activated Ras induces growth arrest in primary mouse embryonic fibroblasts; growth arrest was accompanied by increased levels of p16, p19 (ARF), and $\mathrm{p} 53$, and abrogated in the absence of either the Ink $4 A / A r f$ or $p 53$ loci. Our results are consistent with the idea that loss of the $p 53$ gene or Ink4A/Arf locus synergizes with Ras. However, we cannot explain why a significant number of type II pneumocytes proliferate and develop into tumors when activated K-Ras is induced in bitransgenic mice wild-type for tumor suppressor genes.

Despite an increased growth rate and a more aggressive appearance (Fig. 6A), both the p53- and Ink4A/Arfdeficient tumors undergo rapid apoptotic regression when doxycycline is withdrawn (Fig. 6B). These findings imply that the apoptotic pathway(s) executed following downregulation of the K-Ras transgene is p53- and Ink $4 A / A r f$-independent. The finding that even tumors that are tumor-suppressor-deficient undergo rapid apoptotic regression is especially important, because the majority of human NSCLCs have mutations affecting either p53 or Ink4A/Arf (Fong et al. 1999). Recently, it has become clear that tumors with p53 mutations are relatively resistant to the classical DNA-damaging chemotherapeutics (Lowe et al. 1994; Smith and Fornace 1995; Giaccia and Kastan 1998; Schmitt et al. 1999), whereas agents such as taxol (Bacus et al. 2001) can cause p53independent apoptosis.

To identify other drugs that might induce $p 53$-independent apoptosis in K-Ras driven cancers, it would be useful to determine the mechanism of apoptosis induced by down-regulation of K-Ras. We have noted a rapid loss of transgene-specific RNA after withdrawal of doxycy- 
cline (Fig. 1B; Table 1). This provides a testable hypothesis concerning the triggering event: tumor cells expressing mutant $K$-Ras may have undergone adaptive changes in their transcriptional program such that they are dependent on continued expression of mutant $K$-Ras for viability. In this scheme, immediately following the decrease in mutant $K$-Ras RNA, the altered transcriptional pattern cannot revert swiftly enough to prevent activation of apoptotic machinery. Microarray-based analysis of gene expression could help identify crucial changes in the transcriptional program that occur with induction, sustained expression, and withdrawal of mutant K-Ras. Another testable hypothesis stems from the observation that levels of endogenous $K$-Ras $4 b$ RNA are consistently suppressed twofold following induction of mutant $K$-Ras and that the levels do not normalize for at least several days after removal of the inducer (Table 1). This raises the possibility that the cells die as a result of a Ras deficiency. This could be addressed experimentally using a different induction system to express wild-type $K$-Ras cDNA on de-induction of $K-\operatorname{Ras} 4 b^{G 12 D}$.

Regardless of the mechanism of apoptosis, however, our findings should encourage continued efforts to discover inhibitors of mutant Ras proteins or of the signaling events they cause, in hopes of triggering p53- and Ink4A/Arf-independent cancer cell death with targeted therapies. STI-571 (Gleevec) is an especially dramatic example of a drug that induces apoptosis by blocking the actions of an activated oncogene product (Druker et al. 1996; Le Coutre et al. 1999; Goldman and Melo 2001). We believe that efforts to find such agents can be assisted by suitable animal models for pre-clinical testing. The model we have described here may be especially attractive for these purposes, because tumor induction is efficient, regulatable, and predictable. Furthermore, the rate of induction and tumor aggressiveness can be enhanced by adding mutations in commonly affected tumor suppressor genes. To assess tumor growth and response to new therapies in different genetic backgrounds, it will also be important to develop efficient means to monitor tumor growth. MRI has been applied to a number of different tumor models (Evelhoch et al. 2000) and we have shown here that MRI is capable of detecting the growth and regression of lung tumors generated by an inducible mutant $K-R a s$ in live mice. This already provides a powerful means to gauge responses to experimental therapies with a minimum number of animals; rapid improvements in resolution and capacity are expected as small animal imaging expands (Budinger et al. 1999).

In summary, we have generated an informative model of human adenocarcinoma of the lung that defines K-Ras as a viable therapeutic target and that could assist in the screening of novel therapies.

\section{Materials and methods}

Generation of plasmid constructs and transgenic mice

The Tet-op-K-Ras $4 b^{G 12 D}$ transgene was constructed as follows. First, a $0.5-\mathrm{kb} \mathrm{BamHI} / B g / I I$ fragment containing the mp-1 in- tron poly(A) sequence (gift of Eric Holland, Memorial SloanKettering Cancer Center, New York) was inserted into the BamHI site of the cloning vector, p-BS-SK (Stratagene). Second, the 0.6-kb XhoI/ Pst I fragment containing mutant active murine $K$-Ras $4 b^{G 12 D}$ cDNA (gift of David Tuveson, Massachusetts Institute of Technology) was inserted into pBS-SK-mp1 via XhoI/PstI. Third, the 0.48-kb XhoI/SalI fragment containing seven direct repeats of the tet-operator sequence $\left(\right.$ Tet- $\left.\mathrm{O}_{7}\right)$ and a minimal CMV promoter was excised from pRev-TRE (Clontech) and inserted into pBS-SK-K-Ras $4 b^{G 12 D}$-mpl via XhoI. Tet-op-KRas $4 b^{G 12 D}$ mice were produced by injecting the $1.6-\mathrm{kb}$ XhoI/ NotI fragment containing the Tet-op-K-Ras $4 b^{G 12 D}$-mp1 intron/ poly(A) construct (Fig. 1) into FVB/N blastocysts according to a standard protocol. Transgenic founders were screened by Southern blotting. Subsequent generations were screened by PCR as described below. CCSP-rtTA tetracycline dependent activator mice were produced as described previously (Tichelaar et al. 2000).

\section{Tumor suppressor gene-deficient mice}

Ink $4 \mathrm{~A} / \mathrm{Arf}^{-1-}$ mice were provided originally by R.A. DePinho (Serrano et al. 1996) and obtained on a mixed genetic background from B. Lewis (Varmus Lab, Memorial Sloan-Kettering Cancer Center, NY). $p 53^{-/-}$mice were produced by Tyler Jacks (Jacks et al. 1994) and obtained in a pure FVB/N background from Jackson Labs (Bar Harbor, Maine).

\section{PCR genotyping}

Tail DNA was isolated using Qiaprep Tail DNeasy isolation kit (QIAGEN) according to the manufacturer's protocol. p53 gene and Ink4A/Arf locus genotyping were performed as described previously (Jacks et al. 1994; Serrano et al. 1996). Detection of the $r t T A$ activator transgene and the $K-R a s 4 b^{G 12 D}$ transgene were done using the following primers: rtTA: rtTA fwd $5^{\prime}$-AAG GTTTAACAACCCGTAAACTCG-3' and rtTA rev 5'-GTG CATATAACGCGTTCTCTAGTG-3' (generates a 330-bp product); $K$-Ras $4 b^{G 12 D}$ K-Ras fwd 5'-GGGAATAAGTGTGATTT GCCT-3' and mp-1 rev 5'-GCCTGCGACGGCGGCATCTGC 3' ( 300-bp product). Reactions were amplified with the following PCR protocol: $95^{\circ} \mathrm{C}$ denaturation for $5 \mathrm{~min}$, followed by 30 cycles of $95^{\circ} \mathrm{C}$ for $30 \mathrm{sec}, 57^{\circ} \mathrm{C}$ for $30 \mathrm{sec}, 72^{\circ} \mathrm{C}$ for $30 \mathrm{sec}$, followed by a $5 \mathrm{~min}$ extension at $72^{\circ} \mathrm{C}$. PCR products were resolved on a $2 \%$ agarose gel.

\section{$R T-P C R$}

Total RNA was isolated from the right accessory lobe using the Strataprep total RNA Miniprep Kit (Stratagene) according to the manufacturer's directions. Samples were treated with RQ1 RNase-Free DNase (Promega) and RT-PCR was performed using Superscript One-Step RT-PCR (Life Technologies) for 35 cycles with an annealing temperature of $57^{\circ} \mathrm{C}$ with $0.25 \mu \mathrm{g}$ of total RNA per sample. Primers for $K-R a s 4 b^{G 12 D}$ detection were K-Ras fwd 5'-GGGAATAAGTGTGATTTGCCT-3' and the transgene-specific 3'UTR primer mpl rev 5'-GCCTGCGACG GCGGCATCTGC-3' ${ }^{\prime} \beta$-actin primers were obtained from Promega. Control reactions were run using Taq polymerase without RT enzyme (Perkin Elmer).

\section{Taq-Man quantitative PCR}

RNA was isolated as detailed above. cDNA was generated from $1 \mu \mathrm{g}$ of total RNA using the Clontech Advantage RT for PCR kit (Clontech). $50 \mu \mathrm{g}$ of cDNA equivalents were amplified for 
GAPDH, transgenic $K$-Ras $4 b^{G 12 D}$, and endogenous $K$-Ras $4 b$ in an ABI-prism 7700 (Perkin Elmer Applied Biosystems) for 40 cycles using SYBR green PCR mix (Perkin Elmer Applied Biosystems) according to manufacturer's directions. Following amplification, the data was processed with the analysis program Sequence Detector v 1.7. For each sample, the level of RNA for the genes of interest was standardized to the level of GAPDH within that sample; subsequently, the level of both transgenic and endogenous $K$-Ras $4 b$ was standardized to the level of endogenous K-Ras found in the nontransgenic cohort. Primers for Taq-Man PCR were the following. Transgenic K-Ras was detected with an upstream primer in exon $4 \mathrm{~b}$ (K-Ras4b-fwd $5^{\prime}$ CAAGGACAAGGTGTACAGTTATGTGACT-3') and a downstream primer in the mp-1 pA (mp-1-real time-rev $5^{\prime}$-GGCATC TGCTCCTGCTTTTG- $3^{\prime}$ ). Endogenous $K$-Ras $4 b$ was detected using primers against the endogenous $3^{\prime} \mathrm{UTR}$ (K-Ras-4b-UTRfwd 5'-GCAGGGTTGGGCCTTACAT-3' and K-Ras-4b-UTR rev 5'-ATGCGTCGCCACATTGAAT-3'). GAPDH was detected using the following primers; GAPDH-fwd 5'-GAAGGT GAAGGTCGGAGTC-3' and GAPDH-rev 5'-GAAGATGGT GATGGGATTTC-3'.

\section{Breeding schemes}

All mice were housed in pathogen-free conditions and handled in accordance with institutional guidelines. Bitransgenic mice were produced by crossing the CCSP-rtTA activator mice to Tet-op-K-Ras ${ }^{G 12 D}$ responder mice. All genotyping was done by PCR as described above. For the production of bitransgenic mice with either a p53 gene deletion or an Ink4A/Arf locus deletion, the following approach was taken. First, the activator line and the responder line were each independently crossed to the homozygous tumor suppressor-deficient line. Progeny heterozygous for the tumor suppressor locus and carrying either the responder or activator transgene were interbred to enrich for transgene and tumor suppressor gene homozygotes. Appropriate offspring were crossed to generate animals that carried one copy of the responder and activator transgenes and were wild-type, heterozygous, or homozygous for targeted mutations at the tumor suppressor loci.

\section{Administration of doxycycline}

Doxycycline (Sigma) was administered via the drinking water, freshly prepared twice a week, at a concentration of $500 \mathrm{mg} / \mathrm{L}$ (Tichelaar et al. 2000).

\section{Tissue harvesting and preparation}

Mice were anesthetized via intraperitoneal injection of avertin. The renal artery was transected, thoracic cavity opened, and the right heart perfused with PBS lacking calcium and magnesium. The trachea was exposed and the lungs inflated with $4 \%$ paraformaldehyde in PBS. Lungs were excised, placed into a 50-mL conical tube with $10 \mathrm{~mL}$ of $4 \%$ paraformaldehyde and fixed overnight at $4^{\circ} \mathrm{C}$, washed once for $5 \mathrm{~min}$ in PBS, placed into $70 \%$ ethanol, and sent for paraffin embedding and sectioning (Histoserv, Rockville, MD). All lungs were sectioned in the same fashion; two random steps were taken $100 \mu \mathrm{m}$ apart. Each step con-

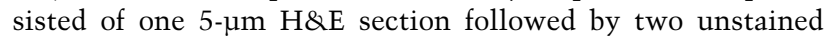
5 - $\mu \mathrm{m}$ sections that were used either for TUNEL assays or immunohistochemistry.

\section{Brdu labeling, immunohistochemistry, and TUNEL assays}

Three hours before sacrifice, Brdu labeling reagent (Zymed Labs) was injected intraperitoneally at a dose of $1 \mathrm{~mL}$ per $100 \mathrm{gm}$ of body weight. Lungs were harvested and fixed in $4 \%$ paraformaldehyde as described above. Following paraffin embedding and sectioning at $5 \mu \mathrm{m}$, Brdu was detected using a Brdu detection kit according to the manufacturer's protocol (Zymed). Polyclonal rabbit-anti-Pro-SP-C (Vorborker et al. 1995) and anti-CCSP were used with an HRP-anti-rabbit kit, according to the manufacturer's protocol (Vector Labs). TUNEL assays were performed on $5-\mu \mathrm{m}$ thick sections as described previously (Gavrieli et al. 1992).

\section{MRI imaging}

Animals were anesthetized initially with $5 \%$ isofluorane in a $55 \%$ nitrogen $/ 45 \%$ oxygen gas mixture. After induction of anesthesia, animals were maintained on $2 \%$ isofluorane in the nitrogen/oxygen mixture. Animals were monitored with respiratory, EKG, and temperature monitoring (BioPac, Anaheim, CA). Mice were placed into a 40-mm diameter MRI probe (Bruker Instruments, Billerica, MA) and a 4.7 T, 40-cm magnet (Oxford Magnetics, Oxford, England) equipped with an Avance console (Bruker Instruments, Billerica, MA). An initial scout image was used to graphically prescribe appropriate coronal and sagittal images to include the lung. Cardiac- and respiratorygated images were obtained with a multi-slice spin-echo sequence with the following imaging parameters: field of view, $6 \mathrm{~cm}$; slice thickness, $2 \mathrm{~m}$; six slices; echo time, $7.4 \mathrm{msec}$; two averages; $256 \times 256$ image matrix.

\section{Acknowledgments}

We thank William Pao (MSKCC) and Pam Schwartzburg (NIHNHGRI) for insightful comments and discussion, Dave Tuveson and Tyler Jacks (MIT) for the K-Ras $4 b^{G 12 D}$ cDNA, Ron DePinho (Dana Farber Cancer Institute) for the Ink $4 a / A f^{-/-}$mice, and Brian Hutchinson (MSKCC) for help with TUNEL staining. We also thank Ricardo Dreyfuss (NIH Photomicrography) for assistance with all figures, Amy Chen and Gene Elliott (NHGRI Transgenic Core) for assistance with generating transgenic mice, and Anastasia René for secretarial assistance. This work was supported in part by grants from the NHBLI (J.A.W.), the Cystic Fibrosis Foundation (J.A.W. and J.W.T.), and the Francis Families Foundation (J.W.T.).

The publication costs of this article were defrayed in part by payment of page charges. This article must therefore be hereby marked "advertisement" in accordance with 18 USC section 1734 solely to indicate this fact.

\section{References}

Bacus, S.S., Gudkov, A.V., Lowe, M., Lyass, L., Yung, Y., Komarov, A.P., Keyomarsi, K., Yarden, Y., and Seger, R. 2001. Taxolinduced apoptosis depends on MAP kinase pathways (ERK and p38) and is independent of p53. Oncogene 20: 147-155.

Berger, W., Setinek, U., Mohr, T., Kindas-Mugge, I., Vetterlein, M., Dekan, G., Eckersberger, F., Caldas, C., and Micksche, M. 1999. Evidence for a role of FGF-2 and FGF receptors in the proliferation of non-small cell lung cancer cells. Int. J. Cancer 83: 415-423.

Budinger, T.F., Benaron, D.A., and Koretsky, A.P. 1999. Imaging transgenic animals. Annu. Rev. Biomed. Eng. 1: 611-648.

Cazorla, M., Hernandez, L., Fernandez, P.L., Fabra, A., Peinado, M.A., Dasenbrock, C., Tillmann, T., Kamino, K., Campo, E., Kohler, M., et al. 1998. Ki-ras gene mutations and absence of p53 gene mutations in spontaneous and urethane-induced early lung lesions in CBA/J mice. Mol. Carcinog. 21: 251-260. Chin, L., Tam, A., Pomerantz, J., Wong, M., Holash, J., Bardeesy, N., Shen, Q., O’Hagan, R., Pantginis, J., Zhou, H., et al. 1999. 
Essential role for oncogenic Ras in tumour maintenance. Nature 400: 468-472.

Clark, J.C., Tichelaar, J.W., Wert, S.E., Itoh, N., Perl, A.K., Stahlman, M.T., and Whitsett, J.A. 2001. FGF-10 disrupts lung morphogenesis and causes pulmonary adenomas in vivo. Am. J. Physiol. Lung Cell. Mol. Physiol. 280: L705-L715.

Downward, J. 1998. Ras signalling and apoptosis. Curr. Opin. Genet. Dev. 8: 49-54.

Druker, B.J., Tamura, S., Buchdunger, E., Ohno, S., Segal, G.M., Fanning, S., Zimmermann, J., and Lydon, N.B. 1996. Effects of a selective inhibitor of the Abl tyrosine kinase on the growth of Bcr-Abl positive cells. Nat. Med. 2: 561-566.

Evelhoch, J.L., Gillies, R.J., Karczmar, G.S., Koutcher, J.A., Maxwell, R.J., Nalcioglu, O., Raghunand, N., Ronen, S.M., Ross, B.D., and Swartz, H.M. 2000. Applications of magnetic resonance in model systems: Cancer therapeutics. Neoplasia 2: $152-165$.

Felsher, D.W. and Bishop, J.M. 1999. Reversible tumorigenesis by MYC in hematopoietic lineages. Mol. Cell 4: 199-207.

Fong, K.M., Sekido, Y., and Minna, J.D. 1999. Molecular pathogenesis of lung cancer. I. Thorac. Cardiovasc. Surg. 118: $1136-1152$.

Forgacs, E., Zochbauer-Muller, S., Olah, E., and Minna, J.D. 2001. Molecular genetic abnormalities in the pathogenesis of human lung cancer. Pathol. Oncol. Res. 7: 6-13.

Gavrieli, Y., Sherman, Y., and Ben-Sasson, S.A. 1992. Identification of programmed cell death in situ via specific labeling of nuclear DNA fragmentation. J. Cell Biol. 119: 493-501.

Gazdar, A.F. and Minna, J.D. 1999. Molecular detection of early lung cancer. J. Natl. Cancer Inst. 91: 299-301.

Giaccia, A.J. and Kastan, M.B. 1998. The complexity of p53 modulation: Emerging patterns from divergent signals. Genes \& Dev. 12: 2973-2983.

Ginsberg, R., Vokes, E., and Rosenzweig, K. 2001. Non-small cell lung cancer. In Cancer: Principles and practice of oncology (eds. V. De Vitta, S. Hellman, and S. Rosenberg), pp. 925-983. Lippencott Williams and Wilkins, Philadelphia, PA.

Glasser, S.W., Korfhagen, T.R., Wert, S.E., and Whitsett, J.A. 1994. Transgenic models for study of pulmonary development and disease. Am. J. Physiol. 267: L489-L497.

Goldman, J.M. and Melo, J.V. 2001. Targeting the BCR-ABL tyrosine kinase in chronic myeloid leukemia. N. Engl. J. Med. 344: 1084-1086.

Greenlee, R.T., Hill-Harmon, M., Murray, T., and Thun, M. 2001. Cancer statistics, 2001. CA Cancer J. Clin. 51: 15-36.

Hanahan, D. and Weinberg, R.A. 2000. The hallmarks of cancer. Cell 100: $57-70$.

Holland, E.C. and Varmus, H.E. 1998. Basic fibroblast growth factor induces cell migration and proliferation after glia-specific gene transfer in mice. Proc. Natl. Acad. Sci. 95: 1218-1223.

Jacks, T., Remington, L., Williams, B.O., Schmitt, E.M., Halachmi, S., Bronson, R.T., and Weinberg, R.A. 1994. Tumor spectrum analysis in p53-mutant mice. Curr. Biol. 4: 1-7.

Johnson, L., Mercer, K., Greenbaum, D., Bronson, R.T., Crowley, D., Tuveson, D.A., and Jacks, T. 2001. Somatic activation of the K-ras oncogene causes early onset lung cancer in mice. Nature 410: 1111-1116.

Kinzler, K.W. and Vogelstein, B. 1996. Lessons from hereditary colorectal cancer. Cell 87: 159-170.

Le Coutre, P., Mologni, L., Cleris, L., Marchesi, E., Buchdunger, E., Giardini, R., Formelli, F., and Gambacorti-Passerini, C. 1999. In vivo eradication of human BCR/ABL-positive leukemia cells with an ABL kinase inhibitor. J. Natl. Cancer Inst. 91: 163-168.

Lowe, S.W. 1999. Activation of p53 by oncogenes. Endocr. Relat. Cancer 6: 45-48.
Lowe, S.W., Bodis, S., McClatchey, A., Remington, L., Ruley, H.E., Fisher, D.E., Housman, D.E., and Jacks, T. 1994. p53 status and the efficacy of cancer therapy in vivo. Science 266: $807-810$.

Malkinson, A.M. 1991. Genetic studies on lung tumor susceptibility and histogenesis in mice. Environ. Health Perspect. 93: 149-159.

Manam, S., Storer, R.D., Prahalada, S., Leander, K.R., Kraynak, A.R., Hammermeister, C.L., Joslyn, D.J., Ledwith, B.J., van Zwieten, M.J., Bradley, M.O., et al. 1992. Activation of the Ki-ras gene in spontaneous and chemically induced lung tumors in CD-1 mice. Mol. Carcinog. 6: 68-75.

Rehm, S., Devor, D.E., Henneman, J.R., and Ward, J.M. 1991. Origin of spontaneous and transplacentally induced mouse lung tumors from alveolar type II cells. Exp. Lung Res. 17: 181-195.

Salgia, R. and Skarin, A.T. 1998. Molecular abnormalities in lung cancer. J. Clin. Oncol. 16: 1207-1217.

Schmitt, C.A., McCurrach, M.E., de Stanchina, E., Wallace-Brodeur, R.R., and Lowe, S.W. 1999. INK4a/ARF mutations accelerate lymphomagenesis and promote chemoresistance by disabling p53. Genes \& Dev. 13: 2670-2677.

Serrano, M., Lee, H., Chin, L., Cordon-Cardo, C., Beach, D., and DePinho, R.A. 1996. Role of the INK4a locus in tumor suppression and cell mortality. Cell 85: 27-37.

Serrano, M., Lin, A.W., McCurrach, M.E., Beach, D., and Lowe, S.W. 1997. Oncogenic ras provokes premature cell senescence associated with accumulation of p53 and p16INK4a. Cell 88: 593-602.

Sherr, C.J. and Weber, J.D. 2000. The ARF/p53 pathway. Curr. Opin. Genet. Dev. 10: 94-99.

Shopland, D.R., Eyre, H.J., and Pechacek, T.F. 1991. Smokingattributable cancer mortality in 1991: Is lung cancer now the leading cause of death among smokers in the United States? J. Nat1. Cancer Inst. 83: 1142-1148.

Smith, M.L. and Fornace, Jr., A.J. 1995. Genomic instability and the role of p53 mutations in cancer cells. Curr. Opin. Oncol. 7: 69-75.

Tichelaar, J.W., Lu, W., and Whitsett, J.A. 2000. Conditional expression of fibroblast growth factor-7 in the developing and mature lung. J. Biol. Chem. 275: 11858-11864.

Tsao, M.S., Liu, N., Nicklee, T., Shepherd, F., and Viallet, J. 1997. Angiogenesis correlates with vascular endothelial growth factor expression but not with Ki-ras oncogene activation in non-small cell lung carcinoma. Clin. Cancer Res. 3: $1807-1814$.

Tuveson, D.A. and Jacks, T. 1999. Modeling human lung cancer in mice: Similarities and shortcomings. Oncogene 18: 53185324.

Vorborker, D.K., Profitt, S.A., Nogee, L.M., and Whitsett, J.A. 1995. Aberrent processing of surfactant protein C (SP-C) in hereditary SP-B deficiency. Am. J. Physiol. 268: L647-L656.

Vousden, K.H. 2000. p53: Death star. Cell 103: 691-694.

Zhang, Z., Wang, Y., Vikis, H.G., Johnson, L., Liu, G., Li, J., Anderson, M.W., Sills, R.C., Hong, H.L., Devereaux, T.R., et al. 2001.Wildtype Kras2 can inhibit lung carcinogenesis in mice. Nat. Gen. 29: 25-33.

Zhao, B., Chua, S.S., Burcin, M.M., Reynolds, S.D., Stripp, B.R., Edwards, R.A., Finegold, M.J., Tsai, S.Y., and DeMayo, F.J. 2001. Phenotypic consequences of lung-specific inducible expression of FGF-3. Proc. Nat1. Acad. Sci. 98: 58985903.

Zsengeller, Z.K., Halbert, C., Miller, A.D., Wert, S.E., Whitsett, J.A., and Bachurski, C.J. 1999. Keratinocyte growth factor stimulates transduction of the respiratory epithelium by retroviral vectors. Hum. Gene Ther. 10: 341-353. 


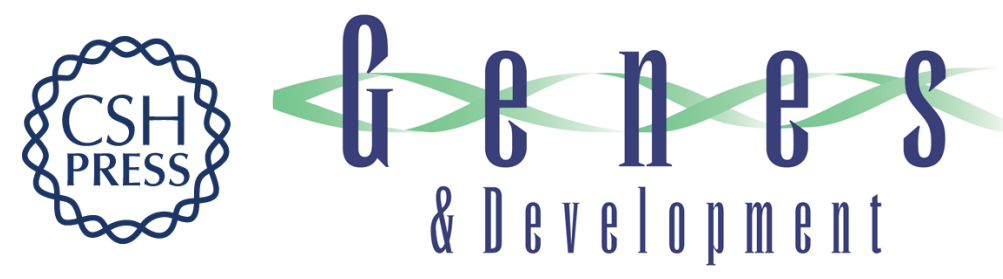

\section{Induction and apoptotic regression of lung adenocarcinomas by regulation of a $K$-Ras transgene in the presence and absence of tumor suppressor genes}

Galen H. Fisher, Shari L. Wellen, David Klimstra, et al.

Genes Dev. 2001, 15:

Access the most recent version at doi:10.1101/gad.947701

\section{References This article cites 44 articles, 10 of which can be accessed free at: http://genesdev.cshlp.org/content/15/24/3249.full.html\#ref-list-1}

\section{License}

Email Alerting
Service

Receive free email alerts when new articles cite this article - sign up in the box at the top right corner of the article or click here.

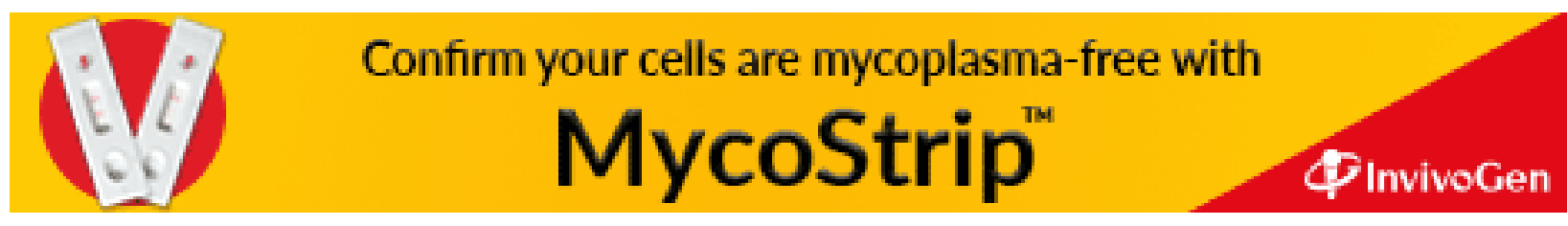

